\title{
Firuze: A Perfect Victim of Suppressed Female Talent in Elif Shafak ${ }^{e e}$ s Black Milk
}

\author{
Alaa Walid Malak \\ Beirut Arab University, P.O. Box 11-5020 Riad El Solh 11072809- Beirut, Lebanon
}

\begin{abstract}
This paper attempts to shed more light on how women's talents and creative abilities are subordinated in the literary realm and how women writers experience what Gilbert and Gubar call "female anxiety of authorship." This study adopts Elif Shafak's creation of an imaginary character named Firuze in Black Milk. It analyzes in depth Shafak's hypothesis on the tragic fate of Firuze. Shafak hypothesizes that "if Fuzuli had a gifted sister, could she have been able to dedicate her life to developing her talent as he had done? What would have been her fate" (Shafak, 2007, p. 31)? Hence, the aim of this paper is to show how Firuze had suppressed her creative talent due to the patriarchal practice that was imposed on her. Although she had made an effort to liberate herself from intellectual imprisonment, Firuze failed and she ended up as a typical victim.
\end{abstract}

Keywords: Elif Shafak, suppression of creative talents, female anxiety of authorship, Firuze, inteelectual imprisonment, Black Milk.

\section{Introduction}

In an attempt to shed more light on how women ee $^{\text {s talents }}$ and creative abilities are suppressed and how women writers experience anxiety of authorship, Shafak depicts the tragic fate of an imaginary character named Firuze. Shafakes creation of Firuze"s story, entitled "A Talented Sister" in Black Milk, is a clear reflection of Virginia Woolfes s creation of a talented female actress named Judith Shakespeare in $A$ Roomof One's Own. As Woolf put her ideas into practice with her creation of Judith Shakespeare, Shafak did the same with her creation of Firuze. The argument of the study is that if Firuze ${ }^{e c}$ creativity was not repressed by the patriarchal creeds of her society, she could have become a great poetess.

This paper is composed of two sections. The first section analyzes in depth how Firuze experiences her "female anxiety of authorship" in Shafak"es Black Milk. The second section focuses on the tragic fate of a talented female character named Firuze.

\section{Firuze and her Experience of Female Anxiety of Authorship in Shafak's Black Milk}

In a chapter entitled "A Talented Sister", Shafak portrays Firuze as a talented girl with a powerful imagination:

"This Firuze is a whiz kid, an explorer by nature, bent on learning, bubbling with ideas. Her mind is full of questions, each tailing the next one. Like images in opposite mirrors, her ideas multiply endlessly, extending into infinite space. Imagination flows out of her sentences like water through the arches of an aqueduct, always fresh, always free... she loves stories, the more adventurous and dangerous the better. Day and night she spins stories about pirates carrying human skulls with rubies set into their eye sockets, magic carpets that fly over spice bazaars and crystal palaces, and two-headed giants who speak a language alien to all ears but hers" (Shafak, 2007, p. 32).
The above passage is taken from Shafakees rumination about the likely fate of Fuzuliees sister: a female figure created by Shafak to stand for all the hidden and ignorant female genius of the past. She is an inquisitive girl with imaginative ideas. This is clearly shown in Shafakes presentation of her as a "girl" who is fond of reading and telling gothic stories. Her voice as a female narrator is of great significance. By narrating gothic stories to her mother and aunts, Firuze uses the "gothic paradigm" and "frame narratives" which is defined as "a literary technique in which an introductory narrative is used to highlight a second muted narrative" (Huizar, 2013, p. 43). This technique is used to "depict the psychological harm to women "s distrust of language "s ability and to convey feminine desires that are caused by a patriarchal structure" (Huizar, 2013, p. 43). Shafak describes Firuze as a girl who spins stories about "two-headed giants who speak a language alien to all ears but hers" (Shafak, 2007, p. 32). This reflects on women"s alienation from literary history and the literary canon. It seems that Firuze is aware that the language that is spoken by the two giants who represent the patriarchy is different from the female language. This is due to the absence of foremothers. As it is represented by Shafak, the language of the two male giants is exotic and alien to Firuze ${ }^{e c}$ mother, grandmother and aunts: "When they can listen no more, she relates her stories to guests, servants and whoever else should come calling" (Shafak, 2007, p. 32). Firuze is aware of her exclusion from traditional historical narratives because of her gender. She has used Gothic historical fiction as a mode of histography which can simultaneously reinsert her into history and symbolize her exclusion. By narrating different stories to her family, Firuze proves to be an imaginative girl. Her elders in the family wonder about her vivid imagination which is deeper than the oceans: "How do you come up with all these stories? Do you sneak to the peak of Kaf Mountain in your sleep and eavesdrop on the talks of fairies till the morning breaks?" (Shafak, 2007, p. 32) They accuse her of moving stealthily to the hill of the Kaf Mountain and listening without permission to the talks of the supernatural beings. This clearly implies that Firuze es foremothers do not believe in the creative power of the female genius. 


\section{International Journal of Science and Research (IJSR) \\ ISSN (Online): 2319-7064 \\ Index Copernicus Value (2013): 6.14 | Impact Factor (2015): 6.391}

Being as gifted as her brother, Firuze longs to follow in the footsteps of her brother. She wants to enroll in a school to study theology, astronomy and alchemy like Fuzuli. Firuze wishes "If only she could walk along the streets proudly carrying books and brick-thick dictionaries under her arms" (Shafak, 2007, p. 34). Not only does she wish to carry books and dictionaries, but also to become a great poetess like her brother. However, Firuze was unable to achieve her wishes because she experienced "anxiety of authorship."

In an attempt to highlight on Firuze s anxiety of authorship, Shafak compares the progress of her writing to an illness that has inflicted and attacked her body and soul. Gilbert and Gubar consider that "any young girl, but especially a lively or imaginative one is likely to experience her education in docility, submissiveness, selflessness as in some sickening" (Gilbert and Gubar, 1979, p.27). Being an imaginative girl, Firuze experiences her anxiety of authorship as a sickening disease. Firuze, as an imaginary female artist, continues to fight "through disease to artistic health" in order to achieve recognition within the dominant discourse. However, her experience of anxiety is increased by her "fear that not only she cannot fight a male precursor on "his" terms and win, but also she cannot "beget" art upon the female body of the muse" (Gilbert and Gubar, 1979, p. 24). The female muse is a literal threat to the male author. Although she helps the male author character creates his best novel, she must be destroyed because she threatens not only his life, but also his authority. Thus, women are denied the possibility of being artists because the muse is responsible for inspiring the male artist. In his theory of "Anxiety of Influence" (1997), Harold Bloom investigates the relationship between the writer, whom Bloom perceives as exclusively male, and the figurative muse, who is exclusively female. The muse "s very existence threatens the male author"s understanding of himself as autonomous and independent. In a precise summary of the implications Freud's theory of psychosexual development has for women, Juliet Mitchell notes that both a boy and a girl, "as they learn to speak and live within society, want to take the father"s [in Bloom "s terminology the precursor"s] place, and only the boy will one day be allowed to do so" (Mitchell, 1975, p. 404-405). In her case, Firuze is unable to take the precursores place because only men are allowed to do so. Her brother Fuzuli is allowed to write poems and he is encouraged by his parents to write more poems. Firuze s creative abilities, on the other hand, are frustrated by her parents. This is revealed when Firuze wishes if her parents would say: "Well done, Firuze. May you become a great poet like your brother" (Shafak, 2007, p. 34). As a result, she was forced to write poems secretly. This reveals how male authority is acknowledged, while female authority appears to be unacknowledged. Thus, Shafakes creation of Firuze reinforces stereotypical gender roles and patriarchal authority, specifically anxieties related to women as writers.

Elaborating on Dickinson's own gender definition, Gilbert and Gubar believe that on the one hand women writers "may ,inhale Despair"e from all those patriarchal texts which seek to deny female autonomy and authority. Women writers may also ,inhale Despair" from all those "foremothers" who have both overtly and covertly conveyed their traditional authorship anxiety to their bewildered descendants. Such traditional metaphorically matrilineal anxiety ensures that even the maker of a text may feel imprisoned within texts folded and "wrinkled" by their pages and thus trapped in their "perpetual seam" which perpetually tells her how she seems" (Gilbert and Gubar, 1979, p. 26). In Firuze "s case, she ,inhales Despair ${ }^{\text {re }}$ from her nanny who acts as her foremother. Her nanny transferred her traditional authorship anxiety to her confused female descendent (to Firuze). This is well revealed when Firuze insists on wanting to become a famous poetess. Her nanny"s reaction is one of sarcasm and mockery. She directly asks Firuze: "Who has ever heard of a female poet" (Shafak, 2007, p.35)? The question depicts authority as a male position, which in turn depicts female creativity as inherently inferior and illegitimate. It seems that the representation of women in relation to writing and to authorship is problematic. Her question also reveals that there is a clear absence of female precursors. Firuze did not have a "literary foremother" or a "model" to follow. The absence of female models reflects anxiety about the possibility of a female voice of authority.

Another example which shows that Firuze es creativity is repressed is when Shafak names her a "forbidden fruit," thus referring to Firuze"s indulgence and pleasure in writing poetry which is considered to be an illegitimate act for women in her society. It is apparent that anxiety is socially constructed through praising the male creative abilities in writing poetry, while ignoring those of females. Shafak alludes to the Biblical story of the forbidden fruit. When Eve ate the apple and seduced Adam to eat as well, she broke God $^{\text {e's }}$ rules. Everything changes and a woman is forever punished by having to endure endless suffering. Thus, the forbidden fruit is of great symbolical meaning! As it establishes a boundary between God and woman, Firuze's poems also establish a boundary between society and female poets. Firuze"s society forbids her and other poetesses from eating this fruit that symbolizes writing poetry. Hence the activity of writing poetry is a forbidden act in a society where men are dominated in the literary world.

In an attempt to discover her talent, Firuze develops into a fiercely independent, self-assured, and moral young woman. This is shown in the decision that she has taken which is to show her brother her poems. Before even looking at them, Fuzuli asks his sister: "Where did you find these poems?" (Shafak, 2007, p.37) Fuzulies question reveals that girls were unable to read and write. Fuzuli expressed his astonishment and surprise when he saw his sister carrying poems. Thus, females were suppressed and deprived of self- expression. Because she knows carefully that to be female means to accept the suffering caused by male dominance in the literary world, Firuze pretends that the poems were written by her neighbor's son and not by her. She, therefore, denies the real author of her poems.

\section{The Tragic Fate of Firuze}

Due to her fear of reprisal, Firuze hides her creative work in hen coops. Here, it is important to shed light on the fate of Firuze "s creative talent. Gilbert and Gubar note that women writers "manage to imply the reason for their deep sense of alienation which is that they have forgotten something" (Gilbert and Gubar, 1979, p. 30). As a result, Firuze has to 
"fight [her] internalization of patriarchal strictures for even a faint trace memory of what [she] might have become" (Gilbert and Gubar, 1979, p. 30). This means that Firuze should struggle against the patriarchal strictures which prevent her from becoming a poetess. Gilbert and Gubar give examples of works where women seem to have "forgotten something." In The Key-Note (1909), Christina Rossetti writes: "Where are the songs I used to know, / where are the notes I used to sing? I have forgotten everything/ I used to know so long ago." In addition to Rossetti, they cite Charlotte Bronte"s Lucy Snowe who "forgets her own history" and Jane Eyre who seems to have "forgotten her family heritage" (Gilbert and Gubar, 1979, p. 30). As Christina Rossetti "forgets" the songs that she used to know, Firuze too "forgets" how to write poems. Shafak compares Firuze"s words to fragments of a broken dream she can no longer remember: "the words Firuze breathes disperse in the wind like shards of a broken dream she once had but no longer remembered" (Shafak, 2007, p. 38). Her inability to find words represents the silencing of women, the limiting of their authorial capability which works to secure them into the role of angel of the house. Hence, the position of the female author is extreme stereotype of the angel. Here arise Shafak"s insightful questions about the hidden talents of many poetesses: "Who knows how many women like Firuze lived throughout Middle Eastern history? Women who could have become great poets or writers but weren't allowed... women who hid their masterpieces in hen coops or dowry chests, where they rotted away" (Shafak, 2007, p. 38)?Shafak"s questions illustrate on the suppression of many female talents and the loss of many female creative energies.

\section{Conclusion}

In conclusion, Firuze is one of the restrained poetesses whose creative powers are simply muffled, silenced, and hushed. Her creative talents, therefore, are hidden, unnoticed, and ignored. Shafak uses Firuze as a tool to clarify the position of a woman endowed with Fuzulies genius but lacking the social conditions. Firuze lacks the power of controlling her life. As a result, she loses her life in addition to her creativity.

\section{References}

[1] Bloom, H. (1997).The Anxiety of Influence: A Theory of Poetry. New York: Oxford University Press.

[2] Gilbert, S. and Gubar, S. (1979).Anxiety of Authorship. In Gilbert, S. and Gubar, S. ,The Mad Woman in the Attic: The Woman Writer and the Nineteenth-Century Literary Imagination. New Heaven: Yale University Press.

[3] Huziar, R. (2013). Anxiety of Female Authorship: Identity and Gender in Radcliffe's A Sicilian Romance and Mary Shelley'sFrankenstein. McnairJournal,15.

[4] Mitchel, J. (1975). Psychoanalysis and Feminism. New York: Vintage.

[5] Shafak, E. (2007). Black Milk: on Writing, Motherhood, and the Harem Within. New York: Viking. 